\title{
Student Engagement on the Implementation of Online English Learning
}

\author{
Putri, N. P. W ${ }^{1 *}$, Hadisaputra, I. N. P2 ., Pratiwi, N. P. A ${ }^{3}$ (D) \\ 1,2,3 English Language Education, Ganesha University of Education, Singaraja, Indonesia
}

\section{A R T I C L E I N F O}

Article history:

Received October 03, 2021

Revised October 04, 2021

Accepted November 17, 2021

Available online December 25, 2021

Kata Kunci:

Keterlibatan Siswa, Pembelajaran

Online, Pembelajaran Bahasa Inggris

Online

\section{Keywords:}

Student Engagement, Online Learning, Online English Learning

DOI:

http://dx.doi.org/10.23887/jpbi.v9i3.40 165

\begin{abstract}
A B S T R A K
Guru bahasa Inggris tidak melibatkan net meeting selama pembelajaran bahasa Inggris online. Temu net sangat penting karena menjadi ruang bagi siswa untuk berkomunikasi dan berinteraksi dengan teman dan guru mereka. Hal ini dapat memicu perasaan, dan mereka tidak ingin terlibat aktif dalam pembelajaran bahasa Inggris online karena mereka tidak dapat merasakan pengalaman mengajar yang sebenarnya dan berinteraksi dengan teman sebaya dan guru mereka secara langsung. Penelitian ini bertujuan untuk menganalisis interaksi siswa dan kesulitan yang terlibat dalam pembelajaran bahasa Inggris online. Penelitian ini menggunakan metode penelitian campuran dengan mengikuti desain penelitian sekuensial explanatory research. Sampel dalam penelitian ini berjumlah 140 siswa dan dipilih dengan teknik cluster random sampling. Proses pengumpulan data dalam penelitian ini dilakukan dengan menyebarkan kuesioner dan melakukan wawancara. Hasil penelitian ini menunjukkan bahwa keterlibatan siswa selama pembelajaran bahasa Inggris online termasuk dalam tingkat tinggi dilihat dari segala aspek. Namun, ada beberapa kesulitan yang terlibat dalam belajar bahasa Inggris online, termasuk masalah koneksi internet, kebosanan, dan kehilangan konsentrasi, yang secara psikologis mempengaruhi motivasi. Kemudian, respon yang lambat membuat siswa kesulitan untuk berkontraksi secara online. Selain itu, keterbatasan pengetahuan bahasa Inggris dan kurangnya interaksi langsung dengan guru, yang membuat siswa memahami materi pelajaran bahasa Inggris secara mandiri, dan kurangnya interaksi langsung dengan sesama siswa juga menjalin persahabatan dengan siswa lain.
\end{abstract}

\begin{abstract}
A B S T RA C T
The English teacher does not involve a net meeting during online English learning. The net meeting is vital because it becomes a space for students to communicate and interact with their friends and teachers. It can trigger feelings, and they do not want to be actively involved in learning English online because they cannot experience the actual teaching experience and interact with their peers and teachers directly. This study aims to analyze student interactions and the difficulties involved in online English learning. This research uses mixed research methods by following a sequential explanatory research design. The sample in this study consisted of 140 students and was selected using the cluster random sampling technique. The process of collecting data in this study was carried out by distributing questionnaires and conducting interviews. The results of this study indicate that the involvement of students during online English learning is included in the high level seen from every aspect. However, there are some difficulties involved in learning English online, including internet connection problems, boredom, and loss of concentration, which psychologically affect motivation. Then, the slow response makes it difficult for students to contract online. In addition, the limited knowledge of English and the lack of direct interaction with the teacher, which makes students understand English subject matter independently, and the lack of direct interaction with fellow students also establish friendships with other students.

This is an open-access article under the CC BY-SA license. Copyright (C) 2021 by Author. Published by Universitas Pendidikan Ganesha.

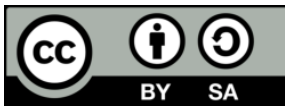

\section{INTRODUCTION}

Corona Virus Disease (Covid-19) pandemic has changed the system of teaching and learning process dramatically which has caused to the shift from the implementation of traditional learning method to the new learning method that enables students and teacher conduct teaching and learning process from home (Khatoony \& Nezhadmehr, 2020; Meriana et al., 2021; Putri et al., 2021). By this situation, online learning becomes the most implemented teaching and learning strategy during this pandemic in almost all school in Indonesia (Al-Idrus et al., 2021; Rahma \& Pujiastuti, 2021; Yoga Purandina \& Astra Winaya, 2020). Online learning refers to the use of the Internet to access learning materials; to interact with the content, instructor, and other learners; and to obtain support during the learning process, in order to acquire knowledge, to construct personal meaning, and to grow from the learning experience (Lestari et al., 2021; Nikolopoulou \& Kousloglou, 2019; Purnamasari et al., 2020). One of important factor that determines the success and quality of online learning is student engagement 
(Hong et al., 2021; Maison et al., 2021; Roni Hamdani \& Priatna, 2020). Students who are engaged in learning are more likely to achieve better grade and performance on standardized tests. Students' grades in online classes are positively correlated with the quality of students' interaction within the course parameters (Hwang et al., 2021; Rusli et al., 2020). Student engagement become primary reason of students' boredom, alienation, and high dropout rate. This clearly reveals that student engagement has contribution to the students' learning achievement (Maican \& Cocoradă, 2021; Octaberlina \& Muslimin, 2020). Students who are engaged more in the learning process may have high achievement whereas disengaged students may end up with having low academic achievement, leave the class early and even end up with dropping out of school.

English teacher in SMKN 1 Tejakula has tried to engage students in online English learning by providing English learning activity that encouraged students' collaborative learning. Besides, English task for students was relevant to their' interest, and real life experiences which created students curiosity and enhanced students engagement in learning. Online English learning in SMKN 1 Tejakula also supported students' autonomy in learning by providing students opportunity to decide and their learning independently. However, English teacher did not involve net meeting during the implementation of online English learning. In fact, net meeting is important as it becomes a space for students to communicate and interact with their friends and teacher. This might result on the feeling of isolated and unwilling to be actively engaged in online English learning because they could not feel actual teaching presence and interact with their peers and teachers directly. In consideration of these factors that encouraged student engagement in online English learning in SMKN 1 Tejakula, it is necessary to measure student engagement in SMKN 1 Tejakula since the student engagement was not fully encouraged by the English teachers especially in interaction with instructor and community support factor.

One of the efforts that can be done to avoid students' low academic achievement and high dropout rate is by measuring student engagement. By measuring the level of student engagement, teachers will be able to effectively plan online learning activities that will encourage students' active participation in the learning process (Koh et al., 2010; Nolen \& Koretsky, 2018; Speight et al., 2018). Measuring engagement helps identify at-risk students since for many students disengagement ends up with dropping out of school. For this reason, measuring student engagement is important to be done as the early action to prevent students' low academic achievement and high dropout rate during the implementation of online learning. In measuring student engagement especially in online learning, the indicators used to measure student engagement need to be focused more on actual learning situations in online learning context (Cinches et al., 2017; Westman \& Bergmark, 2018). For this reason, previous research have identified and developed 6 indicators that can be used to measure student engagement in online learning environment including psychological motivation, peer collaboration, cognitive problem solving, interaction with instructor, community support, and learning management (Lee et al., 2019).

Student will be engaged in online learning when they have psychological motivation to learn, work collaboratively to discuss knowledge and assignment with their peers, and can comprehend and apply the knowledge to the real life situation (Dong et al., 2020; Mpungose, 2020; Usher et al., 2021). Besides, student engagement in online learning is affected by interaction with teacher and other students. Continuous interaction with teacher such as asking for learning assistance gives students chance to feel teaching presence while interaction with other students give the students chance to feel the connection among all students and the sense of belonging to the class community (Butnaru et al., 2021; Laksana, 2020; Suriyani Djamdjuri \& Kamilah, 2020). Both teaching presence and sense of belonging to class community is important to encourage student engagement in online learning. Moreover, as online learning necessitates students to study independently, student' self-directed learning management also becomes important factor for student engagement such as managing learning schedule and place (Ali, 2020; Simamora, 2020; Vlachopoulos, 2020). Those six factors are necessary to be considered by teachers to keep student engaged especially in the implementation of online learning during this pandemic.

Some relevant studies on measuring student engagement in online learning have been done by some researchers. First research have conducted survey study to examine student engagement strategies which involved online students at eight universities across the United States (Martin \& Bolliger, 2018). This study examined student engagement on three factors, learner-to-learner, learner-to-instructor, and learner-to. Other research done mixed method study to investigate student engagement and students' limitation and supporting factors in the implementation of online discussion (Ubu et al., 2021). She measured student engagement by using 5 indicators namely cognitive engagement, behavioral engagement, emotional engagement, and social engagement. Other research also have also done a study on investigating the level of EFL students' engagement in English classes and their feelings towards receiving instruction in English classes in an online environment (Oraif \& Elyas, 2021). They measured student engagement based on students' skill engagement, emotional engagement, participation/interaction engagement, and performance engagement.

Based on those several relevant studies, it could be seen that little attention focused on investigating difficulties that faced by students when engaged in online learning. Thus this study tried to explore deep understanding about the level of student engagement and difficulties faced by students when engaged in online learning. Besides, the measurement of student engagement in this study would be focused on 6 indicators that 
represents more actual learning situation in online learning context namely psychological motivation, peer collaboration, cognitive problem solving, interaction with instructor, community support, and learning management. This study aims to analyze student interactions and difficulties involved in learning English online at SMKN 1 Tejakula. By this study, it was expected that English teachers would know the level of their student engagement and understand the difficulties faced by students when engaged online English learning. Then, it could be used as consideration to improve the implementation of online English learning especially in SMKN 1 Tejakula in the future.

\section{METHOD}

The design of this study was explanatory sequential mixed method design. It was done by collecting and analyzing quantitative data in the first phase and then continued by collecting and analyzing qualitative data in the second phase to help explain or elaborate on the quantitative results (Creswell, 2012). Quantitative data about the level of student engagement in online English learning was collected by administering student engagement questionnaire while qualitative data about difficulties hindering student engagement in online English learning was collected through interview. Student engagement questionnaire used to collect data was adapted which consists of 6 factors namely psychological motivation, peer-collaboration, cognitive problem solving, interaction with instructor, community support, and learning management (Lee et al., 2019).

The sample of this study involved all tenth grade students of hotel accommodation program in SMKN 1 Tejakula which consisted of 140 total students. It was selected by using cluster random sampling technique. For the interview, it involved 6 students who were chosen by using purposive sampling technique based on their level of engagement. The result of student engagement questionnaire was analyzed descriptively to get the mean score of each item. Then the mean score of each item was categorized based on the mean criteria to get the level of engagement. On the other hand, the result of interview was analyzed by following qualitative analysis model by Miles \& Huberman including data collection, data reduction, data display, and conclusion drawing (Miles et al., 2014). The mean criteria that was used to categorized the level of student engagement is presented in Table 1.

Table 1. The Mean Criteria for Student Engagement Questionnaire

\begin{tabular}{llll}
\hline No & Criteria & Score Range & Categorization \\
\hline 1 & $\mathrm{X} \geq \mathrm{Mi}+1.5 \mathrm{SDi}$ & $\mathrm{X} \geq 3.25$ & Very High \\
2 & $\mathrm{Mi}+0.5 \mathrm{SDi} \leq \mathrm{X}<\mathrm{Mi}+1.5 \mathrm{SDi}$ & $2.75-3.24$ & High \\
3 & $\mathrm{Mi}-0.5 \mathrm{SDi} \leq \mathrm{X}<\mathrm{Mi}+0.5 \mathrm{SDi}$ & $2.25-2.74$ & Average \\
4 & $\mathrm{Mi}-1.5 \mathrm{SDi} \leq \mathrm{X}<\mathrm{Mi}-0.5 \mathrm{SDi}$ & $1.75-2.24$ & Low \\
5 & $\mathrm{X} \leq \mathrm{Mi}-1.5 \mathrm{SDi}$ & $\mathrm{X} \leq 1.74$ & Very Low \\
\hline
\end{tabular}

\section{RESULT AND DISCUSSION}

\section{Result}

The research finding presents the result of (1) student engagement level in online English learning and (2) students' difficulties when engaged in online English learning. The process of collecting quantitative data about the level of student engagement in Online English learning was done by administering Student Engagement Questionnaire to 140 students in SMKN1 Tejakula who learned English through online method. The result of student engagement questionnaire is presented in Table 2.

Table 2. The Result of Student Engagement Questionnaire.

\begin{tabular}{|c|c|c|c|c|}
\hline No & Items & Mean & $\begin{array}{l}\text { Total } \\
\text { Mean }\end{array}$ & Category \\
\hline 1. & Online English classes enhance my interest in learning & 2.65 & & \\
\hline & I am motivated to study when I take an online English classes & 2.99 & & \\
\hline 3. & Online English classes are very useful to me. & 3.14 & 2.83 & High \\
\hline 4. & It is very interesting to take online English classes. & 2.68 & & \\
\hline & After taking an online English lesson, I look forward to the next one. & 2.86 & & \\
\hline 6. & I am satisfied with the online English class I am taking. & 2.64 & & \\
\hline 7. & I study the English lesson contents with other students. & 3.06 & & \\
\hline 8. & $\begin{array}{l}\text { I try to solve difficult problems collaboratively with other } \\
\text { students when I encounter them }\end{array}$ & 3.16 & & \\
\hline 9. & I work with other students on English online projects or assignments. & 3.06 & 3.09 & High \\
\hline
\end{tabular}




\begin{tabular}{|c|c|c|c|c|}
\hline No & Items & Mean & $\begin{array}{l}\text { Total } \\
\text { Mean }\end{array}$ & Category \\
\hline & $\begin{array}{l}\text { I ask other students for help when I can't understand a concept } \\
\text { taught in my online English class. }\end{array}$ & 3.17 & & \\
\hline 11. & $\begin{array}{l}\text { I try to answer the questions that other students ask during } \\
\text { English online discussion. }\end{array}$ & 3.00 & & \\
\hline 12. & $\begin{array}{l}\text { I can derive new interpretations and ideas from the knowledge I } \\
\text { have learned in my online English classes }\end{array}$ & 3.04 & & \\
\hline 13. & $\begin{array}{l}\text { I can judge the value of the information related to the } \\
\text { knowledge learned in my online English classes. }\end{array}$ & 3.01 & 3.00 & High \\
\hline 14. & $\begin{array}{l}\text { I tend to apply the knowledge I have learned in online English } \\
\text { classes to real problems or new situations. }\end{array}$ & 2.94 & & \\
\hline 15. & I communicate with my English teachers privately for extra help. & 2.88 & & \\
\hline 16. & I often ask the English teachers about the contents of the lesson & 2.96 & 2.92 & High \\
\hline 17. & I feel a connection with the students who are in my online English classes. & 3.12 & 3.04 & High \\
\hline 18 & I feel a sense of belonging to the online English class community. & 2.99 & & \\
\hline 19. & I frequently interact with other students in my online English classes & 3.00 & & \\
\hline 20. & I study related English learning contents by myself after the online lesson. & 2.89 & & \\
\hline 21. & $\begin{array}{l}\text { I remove all distracting environmental factors when taking online English } \\
\text { classes. }\end{array}$ & 3.01 & & \\
\hline 22. & I manage my own learning using the online system. & 2.91 & 2.96 & High \\
\hline & When I take an online English course, I arrange a learning schedule & 3.02 & & \\
\hline & Total & & 2.98 & High \\
\hline
\end{tabular}

Table 2 showed that the total mean score for student engagement in Online English learning in SMKN 1 Tejakula was 2.98. Based on the mean criteria by Koyan (2012), it was categorized as high level. Therefore, it indicated that student engagement in Online English learning in SMKN 1 Tejakula in general was high in all aspects. For psychological motivation aspect, the mean score reached 2.83 score in which based on the mean criteria it referred to the high level of engagement. This outcome indicated that students in SMKN 1 Tejakula were interested enough to conduct online English learning, had high motivation, expectation, and they felt satisfied enough with the implementation of online English learning. The total mean score of student engagement based on aspect of peer collaboration was 3.09 which means that student engagement was in high level. The mean score of each item were considered high which indicated that students were highly engaged in collaborative activity including participating in online English discussion, discussing English lesson content and assignment, and solving difficult problem with their friends. Besides, for cognitive problem-solving aspect, the mean score reached 3.00 which referred to High engagement. This revealed that from knowledge they have learned in online English learning, they were able to derive an idea, judge the value of information, and apply the knowledge to real life problem. In addition, total mean score for student engagement based on interaction with instructor was 2.92 which indicated that the students highly interacted with their English teacher to get English learning assistance. The students also felt the connection with other students in English class, felt the sense of belonging to the online English class community, and had highly interacted with their classmates. It could be seen from the total mean score for community support aspect was 3.04 was categorized as high level. Moreover, students in SMKN 1 Tejakula were self-directed in managing their learning including managing their learning environment, schedule and managing their learning using online system which could be seen from the total mean score of learning management aspect that reached 2.96 which indicated that student engagement in learning management aspect was in high level.

Students' difficulties when engaged in Online English learning was investigated by interviewing 6 students with different level of engagement in SMKN 1 Tejakula. Based on the result of interview, it was found that students' difficulties when engaged in online English learning appeared in four aspects of student engagement including psychological motivation, cognitive problem solving, peer collaboration, and community support. The result of interview about students' difficulties when engaged in online English learning is presented in the following part. The result of interview revealed that students felt less interested in learning when internet connection problem suddenly appeared in their online English learning. Internet connection problem includes low internet connection and out of internet data that sometimes happened during their online English learning process. In addition, boredom was also faced by students which affect their interest. Boredom appeared because in online English learning, their sights were focused on phone and there were no activity and interaction entertaining their feeling. Besides of internet connection problem and boredom, students sometimes felt uninterested to learn English online because they felt hard to be concentrated in learning. It was due to distracting learning environment 
especially noise from people and activities around the learning place and distraction from their desire to play on social media.

In peer-collaboration aspect, students felt hard to discuss knowledge and assignment with their friends because they were not online at the same time. They did not directly get the respond from their peers and had to wait for other students' responds for a long period of time during the online discussion. This situation showed that delayed feedback from their peers made it hard for students to keep discussing Online English learning material and assignment with their friends. In addition, for cognitive problem solving aspect it was found that students found it difficult to be engaged cognitively because they have limited capability in English language and no chance for them to have live interaction with their English teacher, it was found that students found it difficult to understand English learning concept independently because they did not master English well. They have less understanding of English vocabularies which made them hard to understand English learning concept and assignment provided by their English teacher. Besides, students felt hard to understand English since they had no chance to have live interaction with English teacher which was actually important for them to get immediate comments and correction to improve their learning.

Based on the result of interview, it was found that students conducted online English learning from the beginning they study in SMKN 1 Tejakula where the students did not know each other yet. They only met each other several time at school which made them hard to get closed with all students. Besides, Online English learning did not involve online meeting which limited their opportunities to interact with their teacher and fellow learners. In addition, some of them did not actively interacted with their peers in online group. By this reason, students in SMKN 1 Tejakula also felt difficult to make connection with all students because they had less chance to have interaction. Based on the result of self-report survey and interview, it showed that in general student engagement on the implementation of online English learning in SMKN 1 Tejakula was in high level. Students showed high engagement in Psychological motivation aspect. This was supported by the result of interview which showed that students in SMKN 1 Tejakula felt online English learning interesting due to its autonomy where students can freely manage their learning in terms of time, place, and way of learning. English online learning also allowed them to access various forms of learning material which was considered motivating and useful. Students also felt motivated by the usefulness of learning English, English task that related to their future, and teacher's effort in teaching which encouraged them to keep engaged in learning. This was in line with Ginting (2021) who found that students tend to be more resilient to the learning problem when they understand the reward and intention of what they do. They would also be willing to devote their full attention toward their learning when they were highly motivated. This signifies that high psychological state of students becomes the reason of students' high engagement in online English learning.

\section{Discussion}

The result of student engagement questionnaire also revealed that students were also highly engaged in collaborative learning activity during online English learning. This was supported by the result of interview in which students worked collaboratively with their friends to discuss online English assignment, share their understanding of English concept, and do peer- review before English middle test and final exam. Those collaborative learning activity gives supportive behavior and increases students' problem solving skills in online learning. This result was in line with research has found that collaboration has significantly enhanced students' critical thinking (Junedi et al., 2020; Kivunja, 2014; Nordgren et al., 2021). It encouraged students' willingness to exert more effort and attracted students' interests to work on more difficult subject. Therefore, students kept engaged in online learning process. In addition, students were found highly engaged in cognitive problem solving activity. Student engagement in cognitive problem solving factor includes students' ability to derive an idea, analyze knowledge, judge the value of information, approach learning with new perspective and apply knowledge to real life problem or situation (Hartini \& Martin, 2020; Schoenfeld, 2016; Titin \& Yokhebed, 2018). From the result of survey and interview, students in SMKN 1 Tejakula were able to comprehend English lesson well, apply English knowledge to their real life situation, and work harder to comprehend English knowledge. Students were also willing to exert more effort in order to cope with their learning problem.

The next factor that contributed to the high level of student engagement in online English learning was Interaction with instructor. The interactions with the instructors including communication acts, such as a asking for extra help or questions regarding the contents of the lesson from the instructor, is considered as an important predictor of student engagement in e-learning (Khan et al., 2021; Lee et al., 2019; Mpungose, 2020). The result of student engagement questionnaire also showed that students' interaction with their English teacher was also high in online English learning. It was strengthened by the result of interview which found that students actively interacted with their English teacher to get academic help including clear explanation of English concept and feedback for learning improvement. These interactions between students and teacher gave the sense of teaching presence for students and support student engagement in online English learning. Learners learn successfully when they feel teacher's presence which is done by having continuous interaction with the instructor in online learning 
(Dong et al., 2020; Joo et al., 2011; Tang et al., 2021). This was consistent with the result who found that teacher' presence including regular feedback and guidance is essential to enhance student engagement in online courses (Goh et al., 2017; Nugroho et al., 2021). Therefore, interaction between students and teacher positively impact on how student engaged on online learning.

Community support aspect of student engagement in online English learning was at high level. From the interview result, students in SMKN 1 Tejakula highly interacted with other students to give supportive behavior with each other. This interaction among students who were enrolled in the same online English class created the sense of belonging to the class community and high connection with their friends. Emotional sense of belonging can be a main factor to prevent dropouts and help students to keep engaged in classes (I Putu Budiariawan, 2019; Lee et al., 2019; Rizqi, 2018). This supportive behavior encouraged students' interest to be more active and engaged in online learning process. Furthermore, students' learning management is considered high in online English learning. The result of interview revealed that students managed their learning independently by arranging learning scheduled and taking note to the deadline of English learning assignment. They were also thoughtful to arrange their learning time and place to find comfortable situation to be concentrated in learning English so that they can avoid distraction from people or activity surroundings. This particular learning behavior indicated that students became self-regulated in learning. Students' self-regulated learning has been found to positively impact on student engagement. Self-regulated learning significantly impact on students' interests, enthusiasm, proactive behavior, and interaction with teacher and other students (Lidiawati \& Helsa., 2021; Moning \& Roelle, 2021; Vrieling et al., 2012).

Despite of highly engaged in all aspect of student engagement, students still faced some difficulties in four aspects including psychological motivation, peer collaboration, cognitive problem solving, and community support. Students faced difficulties to keep their interest in learning due to internet connection problem, boredom, and losing concentration during their learning. Focusing their attention to the lesson becomes the problem for students to be engaged in learning (Sorensen, 2013; Susanti, 2020). In this study, students easily lose their concentration due to students' desire of playing on social media and distraction from people or activity around the learning place. This resulted on difficulty to keep interested in online English learning process. In peer collaboration aspect, students seemed difficult to be engaged in online English discussion due to asynchronous learning issue where the students felt hard to get instant feedback from their peers. It made students hard to communicate and interact simultaneously with other students to conduct online discussion and collaborative learning activity because they have to wait for the feedbacks in a long period of time (Ja'ashan, 2020; Perveen, 2016). The result stated that delayed feedback can be another frustrating factor in asynchronous learning environment. Therefore, it could be said that delayed feedback has been found hindering students collaborative learning especially online English discussion in this study.

Besides, students also felt hard to understand English learning independently due to students' low English language mastery. The learning concept that was presented in English made the students hard to derive idea and interpretation since the students even hardly understanding the language. Difficulties in student cognitive engagement where the students hardly communicating their ideas, completing the assignment, and connecting previous lesson with material being studied (Akyol \& Garrison, 2011; Ja'ashan, 2020; Susanti, 2020). Students' difficulties in cognitive problem-solving aspect require more attention from English teacher since this engagement directly affects to students' academic achievement (Junedi et al., 2020; Taqiyyah et al., 2017). That's why more encouraging learning activity and teaching need to be involved in online English learning process to engage students cognitively. Moreover, this present study also revealed that students felt hard to feel the connection with all students in their online English class. The result of interview revealed that net meeting was not involved in online English learning which resulted on insufficient opportunity to have live interaction among students. In fact, involving net meeting is important to provide sufficient opportunity for students to communicate and interact with other students.

The results of this present study are in line with those some previous relevant research concerning the measurement of online English learning (Nartiningrum \& Nugroho, 2020; Nugroho et al., 2021; Suriyani Djamdjuri \& Kamilah, 2020). Students will be highly engaged in online learning when they had positive psychological state in terms of motivation, interest, and satisfaction. They are also highly engaged when they frequently communicate with their English teacher to get learning assistance and actively interact with their friends to work collaboratively in discussing online concept and assignment. The support behavior from students who are enrolled in the same online classes also contributes to the level of student engagement in online learning. In addition, student engagement level was also affected by students' ability to understand and utilize knowledge and their ability to be self-regulated in managing their online learning. Despite of the similarities, this present study showed different point in term of the indicators used to measure student engagement. Most of the previous studies refer student engagement into 3 main dimensions of student engagement including behavioral, cognitive, and emotional engagement. However, the measurement of student engagement and investigation on students difficulties in this study have been done by using more specific indicators that reflect more actual learning situation 
in online learning context namely psychological motivation, peer collaboration, cognitive problem solving, interaction with instructor, community support, and learning management.

\section{CONCLUSION}

There are two points that can be concluded from this study. Firstly, student engagement in Online English learning was in high level. They had high psychological motivation to learn, worked collaboratively with their friends, comprehended English concept well, and applied English knowledge to their daily life or real life situation. Besides, they actively communicated with their English teacher to get learning help, interacted with their friends to sense the belonging to class community, and managed their learning time and place properly. Despite of highly engagement in online English learning, students in SMKN 1 Tejakula sometimes felt difficult to keep their interest, hard to understand online English lesson content independently, difficult to conduct online English discussion and build connection among students in their class. Those difficulties faced by students were due to internet connection problem, boredom, losing concentration, delayed feedback, limited English mastery, and lack of live interaction.

\section{REFERENCES}

Akyol, Z., \& Garrison, D. R. (2011). Understanding cognitive presence in an online and blended community of inquiry: Assessing outcomes and processes for deep approaches to learning. British Journal of Educational Technology, 42(2), 233-250. https://doi.org/10.1111/j.1467-8535.2009.01029.x.

Al-Idrus, S. W., Muti'ah, M., \& Rahmawati, R. (2021). Pengembangan Kemampuan Berpikir Kreatif Mahasiswa melalui Pembelajaran Berbasis Proyek pada Mata Kuliah Kimia Lingkungan di Masa Pandemic Covid 19. AS-SABIQUN, 3(1), 14-25. https://doi.org/10.36088/ASSABIQUN.V3I1.1117.

Ali, W. (2020). Online and Remote Learning in Higher Education Institutes: A Necessity in light of COVID19 Pandemic. Higher Education Studies, 10(3), 16-25. https://doi.org/10.5539/hes.v10n3p16.

Butnaru, G. I., Niță, V., Anichiti, A., \& Brînză, G. (2021). The effectiveness of online education during covid 19 pandemic - a comparative analysis between the perceptions of academic students and high school students from romania. Sustainability (Switzerland), 13(9). https://doi.org/10.3390/su13095311.

Cinches, M. F. C., Russell, R. L. V., Chavez, J. C., \& Ortiz, R. O. (2017). Student engagement: Defining teacher effectiveness and teacher engagement. Journal of Institutional Research in South East Asia, $15(1)$.

Creswell, J. W. (2012). Educational Research: Planning, Conducting, and Evaluating Quantitatine and Qualitative Research (4th ed.). Pearson Education, Inc.

Dong, C., Cao, S., \& Li, H. (2020). Young Children's Online Learning during COVID-19 Pandemic: Chinese Parents' Beliefs and Attitudes. Child Youth Serv Rev, 118. https://doi.org/10.1016/j.childyouth.2020.105440.

Goh, W. W., Wong, S. Y., Ayub, E., \& Lim, C. (2017). The Importance of Teacher's Presence and Engagement in MOOC Learning Environment: A Case Study. IEE Conference on E-Learning, and e-Management. https://doi.org/10.1109/IC3e.2017.8409250.

Hartini, T. I., \& Martin, M. (2020). Pengaruh Penggunaan Model Pembelajaran Problem Solving Sistematis terhadap Hasil Belajar Fisika Dasar 2 Materi Listrik Arus Searah pada Mahasiswa Pendidikan Fisika. Silampari Jurnal Pendidikan Ilmu Fisika, 2(2), 163-174. https://doi.org/10.31540/sjpif.v2i2.1101.

Hong, J.-C., Lee, Y.-F., \& Ye, J.-H. (2021). Procrastination predicts online self-regulated learning and online learning ineffectiveness during the coronavirus lockdown. Personality and Individual Differences, 174, 110673. https://doi.org/10.1016/j.paid.2021.110673.

Hwang, G.-J., Wang, S.-Y., \& Lai, C.-L. (2021). Effects of a social regulation-based online learning framework on students' learning achievements and behaviors in mathematics. Computers \& Education, 160. https://doi.org/10.1016/j.compedu.2020.104031.

I Putu Budiariawan. (2019). Hubungan Motivasi Belajar Dengan Hasil Belajar pada Mata Pelajaran Kimia. Jurnal Pendidikan Kimia Indonesia, 3(2). https://doi.org/10.23887/jpk.v3i2.21242.

Ja'ashan, M. (2020). The Challenges and Prospects of Using E-learning among EFL Students in Bisha University. Arab World English Journal, 11(1), 124-137. https://doi.org/10.24093/awej/vol11no1.11.

Joo, Y. J., Lim, K. Y., \& Kim, E. K. (2011). Online university students' satisfaction and persistence: Examining perceived level of presence, usefulness and ease of use as predictors in a structural model. Computer and Education, 57(2). https://doi.org/10.1016/j.compedu.2011.02.008.

Junedi, B., Mahuda, I., \& Kusuma, J. W. (2020). Optimalisasi keterampilan pembelajaran abad 21 dalam proses pembelajaran pada Guru MTs Massaratul Mut'allimin Banten. Transformasi: Jurnal Pengabdian Masyarakat, 16(1), 63-72. https://doi.org/10.20414/transformasi.v16i1.1963. 
Khan, M. A., Vivek, Nabi, M. K., Khojah, M., \& Tahir, M. (2021). Students’ Perception towards E-Learning During Covid-19 Pandemic In India: An Empirical Study. Sustainability, 13(1). https://doi.org/10.3390/su13010057.

Khatoony, S., \& Nezhadmehr, M. (2020). EFL teachers' challenges in integration of technology for online classrooms during Coronavirus (COVID-19) pandemic in Iran. AJELP: Asian Journal of English Language and Pedagogy, 8(2), 1-16. https://doi.org/10.37134/ajelp.vol8.sp.1.2020.

Kivunja, C. (2014). Do You Want Your Students to Be Job-Ready with 21st Century Skills? Change Pedagogies: A Pedagogical Paradigm Shift from Vygotskyian Social Constructivism to Critical Thinking, Problem Solving and Siemens' Digital Connectivism. International Journal of Higher Education, 3(3), 81-91. https://doi.org/10.5430/ijhe.v3n3p81.

Koh, J. H. L., Herring, S. C., \& Hew, K. F. (2010). Project-based learning and student knowledge construction during asynchronous online discussion. Internet and Higher Education, 13(4), 284291. https://doi.org/10.1016/j.iheduc.2010.09.003.

Koyan. (2012). Statistik Pendidikan Teknik Analisis Data Kuantitatif. Universitas Pendidikan Ganesha Press.

Laksana, D. N. L. (2020). The Implementation Of Online Learning During COVID-19 Pandemic: Student Perceptions In Areas With Minimal Internet Access. Journal of Education Technology, 4(4), 502509. https://doi.org/10.23887/jet.v4i4.29413.

Lee, J., Song, H. D., \& Hong, A. J. (2019). Exploring factors, and indicators for measuring students' sustainable engagement in e-learning. Sustainability, 11(4). https://doi.org/10.3390/su11040985.

Lestari, K. B., Dwi Lestari, I. F., \& Santoso, I. (2021). The Impact of Health Education Using Online Learning on Adolescent Knowledge of Anaemia. KnE Social Sciences, 2021, 209-220. https://doi.org/10.18502/kss.v5i3.8541.

Lidiawati, K. R., \& Helsa. (2021). Online Learning during Covid-19 Pandemic: How Self- Regulated Learning Strategies Impact Student Engagement? Jurnal Psibernetika, 14(1). https://doi.org/10.30813/psibernetika.v14i1.2570.

Maican, M. A., \& Cocoradă, E. (2021). Online foreign language learning in higher education and its correlates during the covid-19 pandemic. Sustainability (Switzerland), 13(2), 1-21. https://doi.org/10.3390/su13020781.

Maison, M., Kurniawan, D. A., \& Anggraini, L. (2021). Perception, Attitude, and Student Awareness in Working on Online Tasks During the Covid-19 Pandemic. Jurnal Pendidikan Sains Indonesia, 9(1), 108-118. https://doi.org/10.24815/jpsi.v9i1.18039.

Martin, F., \& Bolliger, D. (2018). Engagement matters: Student perceptions on the importance of engagement strategies in the online learning environment. Online Learning Journal, 22(1). https://doi.org/10.24059/olj.v22i1.1092.

Meriana, T., Angelius Domes, A., -, Y., \& Sihotang, H. (2021). The Impact of the Covid-19 Pandemic on Students Behaviour During Online Learning at Pelangi Kasih Elementary School in Jakarta. Advances in Social Sciences Research Journal, 8(4), 594-604. https://doi.org/10.14738/assrj.84.10112.

Miles, M. B., Huberman, A. M., \& Saldana, J. (2014). Qualitative Data Analysis.

Moning, J., \& Roelle, J. (2021). Self-regulated learning by writing learning protocols: Do goal structures matter? Learning and Instruction, 75. https://doi.org/10.1016/j.learninstruc.2021.101486.

Mpungose, C. B. (2020). Emergent transition from face-to-face to online learning in a South African University in the context of the Coronavirus pandemic. Humanities and Social Sciences Communications 2020 7:1, 7(1), 1-9. https://doi.org/10.1057/s41599-020-00603-X.

Nartiningrum, N., \& Nugroho, A. (2020). Online Learning amidst Global Pandemic: EFL Students , Challenges ,Suggestions, and Needed Materials. Academic Journal of English Language and Education, 4(2), 115-140. https://doi.org/10.29240/ef.v4i2.1494.

Nikolopoulou, K., \& Kousloglou, M. (2019). Mobile Learning in Science: A Study in Secondary Education in Greece. Creative Education, 10(06), 1271-1284. https://doi.org/10.4236/ce.2019.106096.

Nolen, S. B., \& Koretsky, M. D. (2018). Affordances of Virtual and Physical Laboratory Projects for Instructional Design: Impacts on Student Engagement. IEEE Transactions on Education, 61(3), 226-233. https://doi.org/10.1109/TE.2018.2791445.

Nordgren, K., Kristiansson, M., Liljekvist, Y., \& Bergh, D. (2021). Collegial collaboration when planning and preparing lessons: A large-scale study exploring the conditions and infrastructure for teachers' professional development. Teaching and Teacher Education, 108. https://doi.org/10.1016/j.tate.2021.103513.

Nugroho, A., Ilmiani, D., \& Rekha, A. (2021). EFL Teachers' Challenges and Insights of Online Teaching amidst Global Pandemic. Metathesis: Journal of English Language, Literature, and Teaching, 4(3), 277. https://doi.org/10.31002/metathesis.v4i3.3195. 
Octaberlina, L. R., \& Muslimin, A. I. (2020). EFL Students Perspective towards Online Learning Barriers and Alternatives Using Moodle / Google Classroom during COVID-19 Pandemic. International Journal of Higher Education, 9(6), 1-9. https://doi.org/10.5430/ijhe.v9n6p1.

Oraif, I., \& Elyas, T. (2021). The Impact of COVID-19 on Learning: Investigating EFL Learners ' Engagement in Online Courses in Saudi Arabia. Education Science, 11(3). https://doi.org/10.3390/educsci11030099.

Perveen, A. (2016). Synchronous and Asynchronous E-Language Learning: A Case Study of Virtual University of Pakistan. Open Praxis, 8(1). https://doi.org/10.5944.openpraxis.8.1.212.

Purnamasari, N., Siswanto, S., \& Malik, S. (2020). E-module as an emergency-innovated learning source during the Covid-19 outbreak. Psychology, Evaluation, and Technology in Educational Research, 3(1), 1-8. https://doi.org/10.33292/petier.v3i1.53.

Putri, A. P., Rahhayu, R. S., Suswandari, M., \& Ningsih, P. A. R. (2021). Strategi Pembelajaran Melalui Daring Dan Luring Selama Pandemi Covid-19 Di Sd Negeri Sugihan 03 Bendosari. Prima Magistra: Jurnal Ilmiah Kependidikan, 2(1), 1-8. https://doi.org/10.37478/jpm.v2i1.728.

Rahma, N. A., \& Pujiastuti, H. (2021). Efektivitas Pembelajaran Daring Matematika Pada Masa Pandemi Covid-19 Di Kota Cilegon [the Effectiveness of Mathematics Online Learning During the Covid-19 Pandemic in Cilegon City]. JOHME: Journal of Holistic Mathematics Education, 5(1), 1. https://doi.org/10.19166/johme.v5i1.3811.

Rizqi, M. R. (2018). Peran Media Gambar Berseri Dalam Meningkatkan Motivasi Kemampuan Menulis Karangan Bahasa Arab. El-Ibtikar. EL-IBTIKAR: Jurnal Pendidikan Bahasa Arab, 7(2). https://doi.org/10.24235/ibtikar.v7i2.3363.

Roni Hamdani, A., \& Priatna, A. (2020). Efektifitas Implementasi Pembelajaran Daring (Full Online) Dimasa Pandemi Covid- 19 Pada Jenjang Sekolah Dasar Di Kabupaten Subang. Didaktik : Jurnal Ilmiah PGSD STKIP Subang, 6(1), 1-9. https://doi.org/10.36989/didaktik.v6i1.120.

Rusli, R., Rahman, A., \& Abdullah, H. (2020). Student perception data on online learning using heutagogy approach in the Faculty of Mathematics and Natural Sciences of Universitas Negeri Makassar, Indonesia. Data in Brief, 29, 105152. https://doi.org/10.1016/j.dib.2020.105152.

Schoenfeld, A. H. (2016). Learning to Think Mathematically: Problem Solving, Metacognition, and Sense Making in Mathematics (Reprint). Journal of Education. https://doi.org/10.1177/002205741619600202.

Simamora, R. M. (2020). The Challenges of Online Learning during the COVID-19 Pandemic: An Essay Analysis of Performing Arts Education Students. Studies in Learning and Teaching, 1(2), 86-103. https://doi.org/10.46627/silet.v1i2.38.

Sorensen, E. (2013). Implementation and student perceptions of e-assessment in a Chemical Engineering module. European Journal of Engineering Education, 38(2), 172-185. https://doi.org/10.1080/03043797.2012.760533.

Speight, L., Crawford, K., \& Haddelsey, S. (2018). Towards measures of longitudinal learning gain in uk higher education: The challenge of meaningful engagement. Higher Education Pedagogies, 3(1), 196-218. https://doi.org/10.1080/23752696.2018.1476827.

Suriyani Djamdjuri, D., \& Kamilah, A. (2020). Whatsapp Media in Online Learning During Covid-19 Pandemic. English Journal, 14(2), 69. https://doi.org/10.32832/english.v14i2.3792.

Susanti, Y. (2020). Student Engagement in EFL On-Line Class. Lingual Journal of Language and Culture, 10(2). https://doi.org/10.24843/LJLC.2020.v10.i02.p02.

Tang, Y. M., Chen, P. C., Law, K. M. Y., Wu, C. H., Lau, Y., Guan, J., He, D., \& Ho, G. T. S. (2021). Comparative analysis of Student's live online learning readiness during the coronavirus (COVID19) pandemic in the higher education sector. Computers \& Education, 168. https://doi.org/10.1016/j.compedu.2021.104211.

Taqiyyah, S. A., Subali, B., \& Handayani, L. (2017). Implementasi Bahan Ajar Sains Berbahasa Inggris Berbasis Metakognitif Untuk Meningkatkan Kemampuan Pemecahan Masalah Siswa SMP. Jurnal Inovasi Pendidikan IPA, 3(2), 224-234. https://doi.org/10.21831/jipi.v3i2.14859.

Titin, \& Yokhebed. (2018). Peningkatan Keterampilan Pemecahan Masalah (Problem Solving) Calon Guru Biologi melalui Pembelajaran Berbasis Kearifan Lokal. Jurnal Pendidikan Matematika Dan IPA, 9(1), 77-86. https://doi.org/10.26418/jpmipa.v9i1.23701.

Ubu, A. C. P., Putra, I. N. A. J., \& Santosa, M. H. (2021). EFL University Student Engagement On The Use Of Online Discussion In North Bali. Language and Education Journal Undiksha, 4(1). https://doi.org/10.23887.leju.v4i1.29938.

Usher, M., Hershkovitz, A., \& Forkosh-Baruch, A. (2021). From data to actions: Instructors' decision making based on learners' data in online emergency remote teaching. British Journal of Educational Technology, 52(4), 1338-1356. https://doi.org/10.1111/BJET.13108. 
Vlachopoulos, D. (2020). COVID-19: Threat or Opportunity for Online Education? Higher Learning Research Communications, 10(1), 2. https://doi.org/10.18870/hlrc.v10i1.1179.

Vrieling, E. M., Bastiaens, T. J., \& Stijnen, S. (2012). Effects of increased self-regulated learning opportunities on student teachers' metacognitive and motivational development. International Journal of Educational Research, 53. https://doi.org/10.1016/j.ijer.2012.03.014.

Westman, S., \& Bergmark, U. (2018). Re-considering the onto epistemology of student engagement in higher education. Educational Philosophy and Theory, https://doi.org/10.1080/00131857.2018.1454309.

Yoga Purandina, I. P., \& Astra Winaya, I. M. (2020). Pendidikan Karakter di Lingkungan Keluarga Selama Pembelajaran Jarak Jauh pada Masa Pandemi COVID-19. Cetta: Jurnal Ilmu Pendidikan, 3(2), 270290. https://doi.org/10.37329/cetta.v3i2.454. 